\title{
Dose Reduction Improvements in Storage Basins of Spent Nuclear Fuel
}

Prepared for the U.S. Department of Energy

Assistant Secretary for Environmental Management

Copyright Lioenes By acceptence of this article, the publisher and/or recipient acknowledgos the U.S. Government's right to rotain a nonexclusivo, royalty-fres license in and to any copyright covering this paper.

Approved for public release; distribution is unlimited 


\title{
Dose Reduction Improvements in Storage Basins of Spent Nuclear Fuel
}

\author{
F. F. Huang
}

Fluor Daniel Northwest, Inc.

F. W. Moore

DE\&S Hanford, Inc.

Date Published

August 1997

To Be Published in

Nuclear Technology

Prepared for the U.S. Department of Energy

Assistant Secretary for Environmental Management

Project Hanford Management Contractor for the

U.8. Department of Energy under Contract DE-AC06-96RL13200

Copyright Lioense By scceptence of this article, the publither and/or recipient acknowledges the

U.S. Government's right to rotain a nonexclusive, royalty-freo ficenso in and to any copyright covering this paper.

Approved for public release; distribution is unlimited 


\section{RELEASE AUTHORIZATION}

Document Number: HNF-SA-3158-FP

Document Title:

Dose Reduction Improvements in Storage Basin of

Spent Nuclear Fuel

This document, reviewed in accordance with DOE Order 1430.1D, "Scientific and Technical Information Management," and DOE G 1430.1D-1, "Guide to the Management of Scientific and Technical Information," does not contain classified or sensitive unclassified information and is:

\section{APPROVED FOR PUBLIC RELEASE}

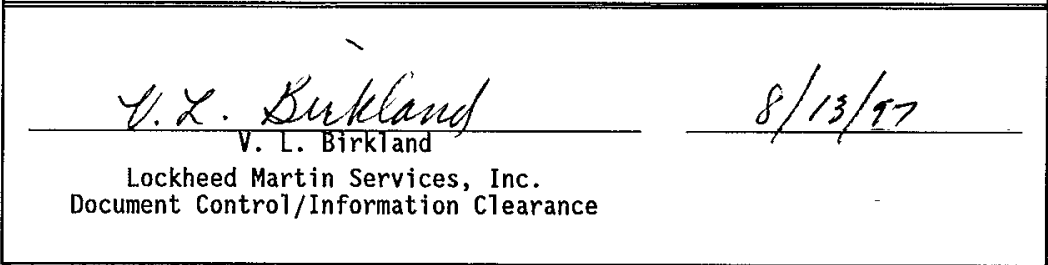

Roviewed for Applied Tochnology, Businose Sensitivo, Classified, Copyrghted, Export Controlled, Patent, Porsonall/pivate, Proprietary, Protected CRADA, Trademark, Unclassified Controlled Nuclear Information.

LEGAL DISCLAIMER. This report was prepared as an account of work sponsored by an agency of the United States Government. Neither the United States Govarnment nor any agency thereof, not any of their employees, nor any of their contractors, subcontractors or their employees, makes any warranty, express or impliod, or as sumes any logal liability or rosponsibility for the accuracy, completenoss, or any third party's use or the results of auch use of any information, apparatus, product, or process disclosed, or represents that its use would not infringe privately owned rights. Reference herein to any speciffe commercial product, process, or service by trade name, trademark, manufacturer, or otherwise, doss not necessarily constitute or imply its endorsement, recommendation, or favoring by the United States Govermment or any agency thereof or its contractors or subcontractors. The views and opinions of authors expressed herein do not necessarily state or refloct those of the United States Government or any agency thereof. This report has been roproduced from the bost wvailablo copy. Printed in the United States of America. Available to the U.S. Department of Enorgy and its contractors from the U.S. Department of Energy Office of Scientific and Technical Information, P.O. Box 62, Oak Ridge, TN 37831: Telephone; 423/576-8401.

Available to the public from the U.S. Departmant of Commerce National Tochnical Information Service, 5285 Port Royal Road, Springfield, VA 22161; Tolephone: 703/487-4650. 
DOSE REDUCTION IMPROVEMENTS IN STORAGE BASINS OF SPENT NUCLEAR FUEL

F. H. Huang and F. W. Moore

August 1997

To be submitted for publication in Nuclear Technology

Duke Engineering \& Services Hanford, Inc. 
for the

U. S. Department of Energy

Richland, Washington

\section{Dose Reduction Improvements in Storage Basin} of Spent Nuclear Fuel

F. H. Huanga and F. W. Mooreb

aFluor Daniel Northwest, Inc.

Richland, Washington, U. S. A

bDE\&S Hanford, Inc

Richland, Washington, U. S. A.

ABSTRACT. Spent nuclear fuel in storage basins at the Hanford Site has corroded and contaminated basin water, which has leaked into the soil; the fuel also had deposited a layer of radioactive sludge on basin floors. The SNF is to be removed from the basins to protect the nearby Columbia River. Because the radiation level is high, measures have been taken to reduce the background dose rate to as low as reasonably achievable (ALARA) to prevent radiation doses from becoming the limiting factor for removal of the SNF in the basins to long-term dry storage. All activities of the SNF Project require application of ALARA principles for the workers. On the basis of these principles dose reduction improvements have been made by first identifying radiological sources. Principal radiological sources in the basin are basin walls, basin water, recirculation piping and equipment. Dose reduction activities focus on cleaning and coating basin walls to permit raising the water level, hydrolasing piping, and placing lead plates. In addition, the transfer bay floor will be refinished to make decontamination easier and reduce worker exposures in the radiation field. The background dose rates in the basin will be estimated before each task commences and after it is completed; these dose reduction data will provide the basis for cost benefit analysis.

\section{INTRODUCTION}

A total of approximately 2100 metric tons of spent nuclear fuel (SNF) was discharged from the 
N Reactor at the Hanford Site before the reactor was shut down in 1988. The SNF has been stored in the K East Basin since 1975 and in the K West Basin since 1981. Although uranium fuel is very reactive chemically, it is clad with Zircaloy and remains stable in basin water. However, some of the fuel in the $\mathrm{K}$ East Basin has corroded because the metal cladding surrounding the fuel has broken. Thus, a small fraction of radioactive material in the fuel has been released into the basin's 3.7 million L water, which has leaked into the soil beneath the $\mathrm{K}$ East Basin in millions of liters. The predominant radionuclides in the basin water are plutonium, cesium and strontium isotopes with concentrations on the order of 1 to $5 \mu \mathrm{Ci} / \mathrm{L}$. To protect the Columbia River, which is only $380 \mathrm{~m}$ from the basins, the highly radioactive fuel in the basins will be removed.

The basin water is also contaminated with uranium and tritium and with debris and sediment that have accumulated on the basin floor, and the average radiation level in the bays of the basins is $16 \mathrm{mrem} / \mathrm{h}$ (16 centimilli $\mathrm{Sv} / \mathrm{h}$ ). As activities related to fuel removal in the basins have increased significantly, dose reduction efforts to minimize worker exposure to radiation are essential for timely completion of fuel removal.

\section{DESCRIPTION OF BASIN}

The basin is a large concrete pool having a width of $20 \mathrm{~m}$, a length of $38 \mathrm{~m}$, and a depth of $6.4 \mathrm{~m}$ (Figure 1). It is divided into three bays of equal size by two concrete divider walls with a water level maintained at a nominal depth of $4.88 \mathrm{~m}$. Both $105 \mathrm{~K}$ East (KE) and $105 \mathrm{~K}$ West (KW) basin facilities were constructed in 1951; they were used to store SNF elements discharged from the $105 \mathrm{KE}$ and $\mathrm{KW}$ reactors. The two basins were designed to operate for 20 years, but were later modified to store N Reactor SNF (uranium) after the KW and KE Reactors were shut down in 1970 and 1971, respectively. The KE basin contains 1150 metric tons of uranium in the form of irradiated fuel that is stored in 3,668 open canisters. In years past, water-filled railroad wellcars were used to transport SNF shielded in casks in the transfer bay. These wellcars will not be used to move the 2100 metric tons of SNF out of the two basins to the 200 East Area for dry 
storage. Instead, a new transportation system is being designed and manufactured to replace the old wellcars and casks.

To meet the requirements of the SNF mission, the basin facilities have been modified for retrieval, cleaning, loading, and removal of the SNF and sludge. The SNF elements will be loaded in a container called the multi-canister overpack (MCO) [1], which will be placed in a cask. The cask then will be loaded in a 3-m-wide, 11.9-m-long and 4.9-m-high trailer with a total gross weight of $47,200 \mathrm{~kg}$. The mezzanines and piping in the transfer bay area will be removed to ensure that the trailer movement through the conveyance path is free of obstruction.

The primary source of external exposure is cesium that has accumulated on the concrete near the waterline. A second source of exposure is corrosion deposits in the piping of the water-cooling system. In addition, the transfer bay floor needs to be sealed to make decontamination easy, because the traffic involved in moving the SNF is expected to be heavy, and radioactive liquids are likely to be spilled. Other facilities to be decontaminated are the overhead areas where the transfer bay crane is operated. In short, the $\mathrm{K}$ Basins facility must be upgraded to reduce the level of radiation to which workers will be exposed during SNF loading and shipping operations. The requirements governing the reduction of radiation are the "As Low As Reasonably Achievable" (ALARA) principles specified in the Code of Federal Regulations, 10 CFR 835 [2].

\section{ALARA REQUIREMENTS}

ALARA is an approach to radiological control intended to manage and control both individual and collective exposure to the work force and general public at levels as low as reasonable, taking into account social, technical, economic, practical, and public policy considerations. All Hanford Site radiological activities require application of ALARA principles as stated in the Hanford Site Radiological Control Manual (HSRCM) [3]. Worker doses are controlled by administrative control levels and are specified in the HSRCM. The same ALARA goals apply to the $105 \mathrm{~K}$ SNF Project. The design activities of the SNF project that involve the 
ALARA process include designs for (1) systems used to remove SNF, sludge, and to treat pool water; (2) equipment such as the casks used to transport SNF; and (3) facilities used to condition and store the SNF for interim storage (e.g., the MCO, facilities for cold and hot vacuum conditioning, and the Canister Storage Building [CSB]).

\section{III.A Dose Management}

The estimated dose rate in the bays of the KE Basin is high (about $16 \mathrm{mrem} / \mathrm{h}$ ) [4]; therefore, the occupational dose must be reduced for completion of the SNF project. However, accurate analysis for design optimization is difficult mainly because the sources of the dose rate include the existing $\mathrm{K}$ Basin source terms as well as those from removal of SNF, sludge, and debris, and from water treatment activities. The occupational exposure may be caused by the dose rate contributions from one or more sub-projects. To ensure compliance with $10 \mathrm{CFR} 835$, a dose management team (DMT) was formed to routinely review the dose estimates for the sub-projects and provide input to the design phase of a project.

The team uses the calculation models to update the estimated dose for the project and each sub-project; radiation field information will then be used to update the models for each subtask. Basically, the input from the team is adapted early in the design process before $\mathrm{K}$ Basin ALARA committee approval for work. The team reviews the project regularly to make sure that ALARA measures are implemented properly.

The DMT and sub-project managers make dose reduction decisions jointly. After the initial dose target for each subproject is identified by the DMT, the managers identify sufficient potential design changes for dose reduction, cost and schedule impacts. The dose target may be revised to support the design changes in terms of cost benefit and schedule impacts. The dose reduction requirement for each subproject then is selected and the design changes implemented for the needs of all projects. 


\section{III.B Dose Reduction Techniques}

The dose rate can be reduced by the function of source reduction, distance, time, and shielding. Examples of source reduction include hydrolasing contaminated piping and removing a layer of contaminated concrete from the pool walls while still underwater will help reduce overall dose rate. Application of the time factor to dose reduction includes reducing the time spent in radiation zone operations by use of mockup activities. Time spent in the radiation area can also be reduced by installing a public address system for better communication and refinishing the floor in the transfer bays. The application of the shielding principles of dose reduction involves the use of lead to shield contaminated piping and raising the water level in the basins.

\section{III.C Program Implementation}

The implementation of the ALARA program is important for cleanup activities in the $\mathrm{K}$ basins as high-activity debris may be encountered. To implement the program, the dose rate in the basins will be constantly monitored by a system of alarming dosimeters and portable radiation monitors.

During SNF loading and shipping in the $\mathrm{K}$ Basins, workers will have waiting periods between transfer operations. Low dose rate areas in the basin buildings have been identified to provide workers with places to wait. This practice is effective in implementing the ALARA program.

The ALARA reviews were performed long before conceptual design to ensure that dose reduction and contamination minimization are integrated into design and construction procedures. Subsequent major design reviews verify that the radiological criteria and practices are incorporated into designs or modifications of facilities. Input from the ALARA support team is provided during the design phase of a project. The support team makes sure that the ALARA input is considered before approval for work is requested. All designs for activities related to the $\mathrm{K}$ Basin projects must be reviewed and approved by the ALARA committee. The dose assessment and 
recommendations for dose reductions provided by the committee then are conveyed to sub-project managers and design authorities for implementation.

\section{DOSE REDUCTION IMPROVEMENTS}

\section{IV.A Radiological Sources}

Over time, radioactive materials leaking from the damaged fuel rods have contaminated basin water, concrete walls, and water cooling system piping [5]. Basin water contains radionuclides such as cesium, strontium, and plutonium. The $137 \mathrm{Cs}$ emits gamma rays, which can be detected to determine the background dose rate in the basins. To maintain water quality in the basins, a sand filter, ion-exchange columns, and ion-exchange modules have been connected to the basin pool. Analysis shows that $137 \mathrm{Cs}, 90 \mathrm{Sr}$, and $239 \mathrm{Pu}$ occur in the basin water in concentration ranges of 1 to $5,0.5$ to 4 , and 0.01 to $0.04 \mu \mathrm{Ci} / \mathrm{L}$, respectively. Air emissions from the $\mathrm{K}$ Basins are presently controlled to a low level by reducing radioactivity concentration in the basin water.

Because uncoated concrete can absorb $137 \mathrm{Cs}$, it is not surprising that significant quantities of $137 \mathrm{Cs}$ from the basin water have penetrated the concrete walls to as deep as $9 \mathrm{~mm}$ with concentrations of 5 to $15 \mu \mathrm{Ci} / \mathrm{cm} 2$. A study of samples of the wall friable layer above and below the water level indicates that $137 \mathrm{Cs}$ is the major contributor to dose rates in the facility.

Water quality has been maintained by a cleaning system that consists of a sand filter, a skimmer pump, and two ion-exchange modules. Decay heat is removed by the basin cooling system, which consists of a chiller, cartridge filter, and recirculating pump. Both systems employ piping. The low flow velocity of water in the cooling system piping has resulted in corrosion in the pipe walls; the contamination in the corrosion layer of this piping contributes 60 to 110 $\mathrm{mrem} / \mathrm{h}$ (centimilli Sv/h) of exposure.

\section{IV.B Raising Basin Water Level}


Analysis of radiation dose rate of the "bathtub ring" in the basin using a computer model indicates that raising the water level will reduce the dose rate. Of concern is the structural stability of the basin with a higher water level during an earthquake. Seismic analyses of the basin with water levels of $4.88 \mathrm{~m}$ and $5.3 \mathrm{~m}$ were performed to evaluate the effects of increases in the water level on changes in wall pressure [6]. Both static and dynamic water and soil pressures were calculated in terms of water level. Analysis shows that increasing the water level significantly decreases the static stresses in the walls but produces only insignificant increases in the hydrodynamic pressure. Thus, an increase in the water level by $46 \mathrm{~cm}$, although it increases the pressure against the wall, reduces the static and seismic forces on the basin mainly because the internal pressure of water is balanced by the external pressure from the soil. Unless the wall has developed cracks, increasing the water level should not affect the structural stability of the basin.

\section{IV.B.1 Dose Model}

The gamma-dose computer code [7] was used to model the KE basin for studies on effects of water level on dose rate. The source terms in the model included the basin water $(5 \mu \mathrm{Ci} / \mathrm{L})$, the "bathtub ring" on the walls $(10 \mu \mathrm{Ci} / \mathrm{cm} 2)$, the return lines $(2 \mu \mathrm{Ci} / \mathrm{cm} 2)$, and the primary water header $(2 \mu \mathrm{Ci} / \mathrm{cm} 2)$. Dose rates were calculated at representative locations $0.9 \mathrm{~m}$ above the gratings in the basin. Water levels of $4.9 \mathrm{~m}, 4.92 \mathrm{~m}, 4.98 \mathrm{~m}$, and additional levels above/below $4.9 \mathrm{~m}$ were modeled. Calculations showed that the dose rate results primarily from the bathtub ring and is reduced significantly by raising the water level $10 \mathrm{~cm}$. The calculations suggested that an increase of $35 \mathrm{~cm}$ in water level would reduce the total collective dose by a factor of 3 .

\section{IV.B.2 Basin Wall Coating}

Before the basin water level is raised, both the perimeter walls and the divider walls had to be coated with an epoxy material to prevent additional penetration by $137 \mathrm{Cs}$ from the basin water. Wall coating was accomplished with motorized clean-and-coat equipment in accordance with 
ALARA principles.

Coating Material An alkylamine-cured epoxy mastic was selected to coat the basin wall; selection of this product was based on results of design-basis accident (DBA) and radiation tests [8]. These tests were performed to search for reliable coating systems for use on damp surfaces above the water line and the dry well, and for use underwater in the wet well. A total of 50 panels (5 by 10 cm) prepared to ASTM D-5139, Section 4, requirements [9] were painted with nine candidate coating materials. Some of these panels were irradiated and DBA tested while some were unirradiated and DBA tested. The irradiated panels received a total integrated dose of $1.1 \times 109$ rads with a dose rate of $2.2 \times 106 \mathrm{rad} / \mathrm{h}$.

Panels of each candidate coating material were evaluated to the standards of ASTM D-4214, D-4541, D-3359, D-3912 [10], and in terms of their capability to be applied underwater, to damp substrates, rusty steel, and over standing water. Both radiated and unirradiated coatings were examined for flaking, delamination, peeling, chalking or blisters after removal from the autoclave, per ASTM D-3911 [11].

Results of the DBA and radiation tests led to the conclusion that the alkylamine-cured epoxy mastic designed for underwater application was the best choice for use within the wet well and that a modified cycloaliphatic amine-cured epoxy and an aliphatic amine-cured epoxy were suitable for coating applications for the dry well of the SNF basins.

Clean and Coat Equipment The fuel pool is covered by steel grating; above the grooves in the floor grating run the monorail tracks used to transport or lift equipment. The floor grating is 1.5 $\mathrm{m}$ above the water surface and $2.1 \mathrm{~m}$ below the bottom of the hoist rails. With such facility constraints, a trolley carriage system was specially designed to clean and coat the basin walls (Figure 2).

The system can be telescoped up and down for deployment above and below the grating in 
the basin; this capability eliminates any need for removal of the grating. The vertical tubes of the system have the top end hung on the monorail hoist system and the bottom end attached to the support channel, which consists of a sliding carriage with an extendable swing arm. A camera attached to the swing arm allows the operators to view cleaning and painting from above the gratings. The equipment has a nylon-bristled rotating brush attachment for superficial cleaning of the walls, with a HEPA vacuum attached to the system above the gratings. The equipment uses a power roller attachment to apply a coating material on the walls; it was lowered below the grating through the opening in the center bay and transported during operation by the monorail/trolley system. This equipment was used to cover a band from the water level up to a distance of $46 \mathrm{~cm}$ on the basin perimeter walls with the selected coating material for the KE basin.

\section{IV.B.3 Results of Dose Reduction}

Raising basin water level is one of the dose reduction tasks to be completed to reduce worker exposures during SNF operations. However, raising the water in the KE required several facility modifications to maintain the environment of the aging fuel. The skimmer weir boxes were replaced and instrumentation was modified. The water level was raised from the $4.9 \mathrm{~m}$ level to the $4.98 \mathrm{~m}$ level and will be increased to a level of $5.23 \mathrm{~m}$ after the basin perimeter walls are painted with the selected coating material.

Results of area dose rate reduction appear in Figures 3 and 4, which depict the dose rates before and after the basin water level was raised by $7.6 \mathrm{~cm} \mathrm{[12].} \mathrm{The} \mathrm{dose} \mathrm{fields} \mathrm{in} \mathrm{the} \mathrm{basin} \mathrm{are}$ simulated with data for a computer model from a complete survey of areas around the grid points. The grid points were permanently established in the basin facility so that the dose rates at the same points can be measured before and after conditions in the basin are changed. As shown in Figures 3 and 4 , raising water level by $7.6 \mathrm{~cm}$ lowers the dose rate by 40 percent. The dose rate field graphs provide information as to which equipment and piping will need to be decontaminated or removed, and which area is optimal for work on the SNF project. 


\section{IV.C Hydrolasing Pipe}

Basin water circulated in the cooling system piping in the KE Basin has caused corrosion in the pipe walls and left radiological deposits inside the recirculation piping (see Section IV.A). The piping needs to be decontaminated internally to reduce worker radiation exposure. The run of piping to be cleaned is approximately $198-\mathrm{m}$ long, mostly in the primary recirculation system.

The hydrolasing equipment consists of a $68.9 \mathrm{MPa}$ pump, high-pressure water hose, a 45.7 m lance, and specially designed nozzles. A small video camera was used to examine the interior of the piping to ensure that the pipe wall thickness was sufficient to withstand the high water pressure. The pump was set up outside the building housing the basin. The high-pressure water hose was attached to one end of the lance whose other end was connected to a nozzle. To begin the hydrolasing process, the nozzle was inserted into the pipe opening and the water pressure was increased until the buildup inside the pipe was removed. Demineralized water without chemicals was used during the operation.

Scale and particulates were pumped back to the basin after a section of the piping was hydrolased; particulates larger than $20 \mu \mathrm{m}$ were collected on a filter. Filters containing radioactive waste were bagged and later disposed of. To maintain water temperature control and soluble concentrations as low as possible, water treatment systems were not shutdown during decontamination activities. Sections of the recirculation piping that were hydrolased included the inlet header, the cartridge filter header, the bypass loop, and the discharge header.

Hydrolasing removed the deposits from the inside of the inlet and outlet valves; it not only reduced the dose rates but also improved valve operation. Hydrolasing the recirculation piping in the $\mathrm{KE}$ basin reduced the general area dose rate by an average of 20 percent. The area dose rate reductions for various areas appear in Table 1 while the contact dose reduction rate is summarized in Table 2 [13]. The largest area and contact dose rate reductions were $27.5 \%$ and $85 \%$, respectively. Raising the basin water level by $2.7 \mathrm{~cm}$ during hydrolasing aided the area dose rate 
reduction. Hydrolasing of additional contaminated piping and valves continues, in hopes further reducing the dose rate in the basin.

\section{IV.D Placing Lead Plate}

Lead plates had to be placed on the grating around the perimeter of the pool and along the divider walls in the $\mathrm{KE}$ basin, because the dose rate was found to be six times higher near the edge of the pool

than in the center of the basin bays due to th e"bathtub ring". The dose rates above the basin water were surveyed before and after the lead plates were in place. On average, shielding reduced the dose rate above the basin pool by 20 percent [13].

Table 1. General Area Dose Rate Reduction by Hydrolasing Piping in Basin Area [13].

\begin{tabular}{llcc}
\hline \multicolumn{1}{c}{$\begin{array}{c}\text { KE Basin } \\
\text { area }\end{array}$} & $\begin{array}{c}\text { Dose rate before } \\
\text { hydrolasing } \\
(\mathbf{m R / h})\end{array}$ & $\begin{array}{c}\text { Dose rate after } \\
\text { hydrolasing } \\
(\mathbf{m R / h})\end{array}$ & $\begin{array}{c}\text { Percent } \\
\text { reduction }\end{array}$ \\
\hline $\begin{array}{l}\text { Dummy elevator } \\
\text { pit }\end{array}$ & 11.9 & 9.2 & 22.8 \\
$\begin{array}{l}\text { Tech. view pit } \\
\text { and weasel pit }\end{array}$ & 6.7 & 4.8 & 27.5 \\
East Bay & 11.6 & 9.8 & 15.3 \\
Center Bay & 14.7 & 11.5 & 21.8 \\
West Bay & 16.5 & 13.7 & 17.0 \\
Average & 12.3 & 9.8 & 20.1 \\
\hline \hline
\end{tabular}

Table 2. Contact Dose Rate Reduction by Hydrolasing Piping [13]. 


\begin{tabular}{llll}
\hline $\begin{array}{c}\text { KE Basin } \\
\text { area }\end{array}$ & $\begin{array}{c}\text { Dose rate before } \\
\text { hydrolasing } \\
(\mathbf{m r e m} / \mathbf{h})\end{array}$ & $\begin{array}{c}\text { Dose rate after } \\
\text { hydrolasing } \\
\text { (mrem/h) }\end{array}$ & $\begin{array}{c}\text { Percent } \\
\text { reduction }\end{array}$ \\
\hline $\begin{array}{c}\text { Recirculation } \\
\text { piping }\end{array}$ & 220 & 60 & 73 \\
$\begin{array}{c}\text { East downcomer } \\
\text { valve }\end{array}$ & 150 & 22 & 85 \\
$\begin{array}{c}\text { Header in tech } \\
\text { view pit area }\end{array}$ & 20 & 15 & 25 \\
\hline \hline
\end{tabular}

\section{IV.E Refinishing Transfer Bay Floor}

As indicated in Section III.B, refinishing the transfer bay floors in the basins reflects application of the source reduction and time factors in an effort to reduce exposure. On the floors are railroad rails with recesses and holes; the floor areas will be used as truck loadout areas to load and ship SNF with a heavy load. As activities related to fuel removal in the basin increase significantly, radioactively contaminated material is likely to accumulate in the recesses and on existing paint if waste liquids are spilled. Therefore, coating the transfer bay floors with a decontaminable coating is an effective measure that not only can reduce contamination cleaning and thereby reducing the possibility of inhalation exposures to workers in the basins, but also can significantly reduce the time spent to put down and take up the contamination control paper to prevent increasing source term in the floors.

\section{IV.E.1 Candidate Coating Materials}

Two generic families of coating materials were considered for decontamination: epoxy and polyurea plastic coatings. Epoxy is known for its superior adhesion properties and its decontaminability, while plastic coating provides a strippable decontamination medium and corrosion/erosion protection. Before coating is added to existing paint, tests must be performed on coating materials to qualitatively evaluate their adhesive strengths and the integrity of their laminating properties. Results of such tests were the basis for selecting the coating material for the 


\section{K Basin floors.}

The special protective coating to be used on the transfer bay area had to provide (1) a surface capable of tolerating heavy loads, abrasive traffic, and impact; and (2) a cleanable surface capable of resisting water permeation, chemicals, and petroleum oils. These requirements indicate that the sealant had to have a minimum tensile strength of $69 \mathrm{MPa}$ and elongation of $5 \%$ at $24 \mathrm{oC}$. The concrete floor and the steel plates might require different coatings.

Polyurea plastic coating materials have been found to have a wide variety of applications in providing a protective coating for decontamination purposes. However, with a tensile strength of only $17 \mathrm{MPa}$, these materials are likely to be damaged by heavy truck and forklift operations but could be replaced periodically. To explore the possibility of using these materials for heavy traffic applications, a laboratory test would have had to be performed by the manufacturer to determine whether the polyurea plastic coating materials can withstand wheels spinning under a heavy load. Polyurea plastic coating materials are not currently included in the field adhesion tests.

\section{IV.E.2 Coating Material Selection}

Several epoxy coating materials used in the nuclear industry have been investigated for possible applications on the $\mathrm{K}$ Basin floors. The coated floor becomes the test substrate when the test is conducted in the field. An area $0.3 \mathrm{~m}$ by $1.2 \mathrm{~m}$ on the floor of the $\mathrm{KW}$ Basin transfer bay near the wall was selected for paint testing. Existing loose paint was removed and the adherent coating on the floor was scrubbed with a general-purpose cleanser before application of the proposed coating materials.

Both primer and finish coats of the four paint products were applied in accordance with the application instructions of the respective manufacturers. Two primers of one paint product were tested for one finish coat; one of the four products required no primer. Five test coupons 10 $\mathrm{cm}$ by $25 \mathrm{~cm}$ each were used. The adhesives were allowed enough time to set up and reach the recommended cure for testing. 
Details of the test procedures can be found in ASTM D4541, "Measuring Pull-Off Strength of Coating by Tester," and in ASTM D3359, "Measuring Adhesion by Tape Test" [10]. In the ASTM D4541 procedure, an adhesion tester is used to test the dolly to obtain the numerical values of adhesion for the coating materials. The dolly is bonded to the prepared test surface of each coating material. The test involves pulling the dolly until failure occurs. The force attained at failure or the maximum force applied is recorded. The results are used to determine the failure modes of adhesive to the existing paint. ASTM D3359 is a qualitative test method requiring that a sharp knife be used to make two cuts in the paint film. The two cuts intersect with a smaller angle of approximately $30 \mathrm{deg}$ (Method A) or, in the case of films thinner than $5 \mathrm{mil}$, at 90 deg to form a grid (Method B). Pressure-sensitive tape is placed at the intersection of the cuts or over the grid. Within 1 to 2 minutes of application, the tape is pulled off rapidly. The adhesive properties can be evaluated by considering ease of separation of the adhesive and determining the failure type.

In the $\mathrm{K}$ Basins tests, results showed that there was no peeling at the cut intersection on any of the coating materials, an indication that the adhesion of the proposed materials to the floor was good and that the tape test was not capable of discriminating among the adhesive strengths of the epoxy products tested. Pull-off tests were performed on three spots for each coating material. After each test, the plug of the coating material bonded to the bottom of the dolly was examined; the sizes of the existing coat and top coat pulled off were measured and compared.

Comparisons of results among the coating materials tested led to the conclusion that the cycloaliphatic amine-cured epoxy $100 \%$ solid epoxy products were suitable for coating the floors of the K Basins. Refinishing contaminated floors with these products is reported elsewhere [14].

\section{COST BENEFITS FROM DOSE REDUCTION}

The major tasks of the dose reduction project involve pipe hydrolasing, placing lead-plate shielding, coating the basin wall and raising the water level, and refinishing the transfer bay floor, as discussed above. Other contaminated equipment and piping, such as the ion exchange columns 
in the transfer bay and ion exchange column service piping and the piping in the west end of the basin, will be evaluated to determine whether there is a need for their decontamination or removal. Also, existing ion exchange or more effective technologies are being considered for removing $137 \mathrm{Cs}$ from the basin water to reduce existing dose rates.

Dose rate reduction produces cost benefits that can be determined by estimating the reduction of collective dose in person-rem in comparison to the money spent for these efforts. The total doses that workers receive during operations to remove SNF from the basins were estimated for the following major tasks: sludge mitigation, day-to-day operations, fuel removal and debris removal. Based on conversations with basin operations staff and review of process flow diagrams, estimates were made for the number of persons, dose rate at work location, and time required to perform each subtask. The total dose of each subtask was obtained by multiplying these three variables.

The initial collective dose estimate for the KE basin was 790 person-rem at $14 \mathrm{mrem} / \mathrm{h}$ (centimilli Sv/h); the dose estimate was subsequently reduced to 650 person-rem after hydrolasing piping, then to 540 person-rem after perimeter shielding with lead plates, and to 332 person-rem at $5 \mathrm{mrem} / \mathrm{h}$ after the basin walls were cleaned and coated and the water level was raised $7.6 \mathrm{~cm}$ higher [15]. It costs approximately $\$ 4000$ per person-rem to complete these sub-projects and to achieve the general area dose rate reduction from 14 to $5 \mathrm{rem} / \mathrm{h}$ (centimilli Sv/h). The projected dose will be reduced even further when the basin water level is raised an additional $36 \mathrm{~cm}$. With the cutoff cost of $\$ 30,000$ per person-rem for dose reduction [15], the cost savings resulting from a reduction of 460 person-rem is significant.

\section{CONCLUSION}

Corroded uranium metal fuel in the $\mathrm{KE}$ storage basin results in an average radiation level of approximately $16 \mathrm{mrem} / \mathrm{h}(16$ centimilli $\mathrm{Sv} / \mathrm{h})$, which is a fairly high for personnel performing operations in the basin. Radiological sources have been identified and dose reduction 
improvements have been made on the basis of ALARA principles. Dose rates in the KE basin were reduced by $58 \%$ after hydrolasing the piping, applying lead-plate shielding, and raising the water level $7.6 \mathrm{~cm}$. Additional efforts will be made to use engineered methods to reduce the dose rate below $5 \mathrm{mrem} / \mathrm{h}$ (centimilli $\mathrm{Sv} / \mathrm{h})$. These efforts will minimize radiation exposures for workers to accomplish the transition of the corroded fuel from wet to dry storage.

\section{REFERENCES}

1. F. H. Huang, "Container materials in environments of corroded spent nuclear fuel, "J. Nuclear Materials 231, PP. 74-82 (1996).

2. 10 CFR 835, Occupational Radiation Protection, Code of Federal Regulations, as amended.

3. Hanford Site Radiological Control Manual, U.S. Department of Energy, Richland Operations Office, Richland, Washington.

4. G. Vargo, J. Durham, E. Hickey, P. Stansbury, and G. Cicotte "Review of ALARA plan for activities at the $105 \mathrm{~K}$-Eest Fuel Storage Basin," PNL-9286, Revision 2, Pacific Northwest Laboratories, Richland, Washington (1994).

5. G. S. Voyles, "Initial project dose and resource assessment." WHC-SD-SNF-TA-008, Westinghouse Hanford Company, Richland, Washington (1996).

6. B. V. Winkel and S. K. Kanjilal, 1050KE/105-KW Irradiated Fuel Storage Basins Seismic Qualification, WHC-SD-NR-SA-024, Westinghouse Hanford Company, Richland, Washington (1991).

7. W. D. Reece, S. D. Miller, J. E. Tanner, and L. A. Sigalla, Waste inventory and estimator, WISE and SIMPLE, An Easy-to-Use Shielding Code, Version 1.0, Pacific Northwest Laboratories, Richland, Washington (1987).

8. D. A. Hill, "Coating damp surfaces within the dry well and wet well of a boiling water reactor nuclear facility," Private Communication, Washington Public Power Supply 
System, Richland, Washington (1996).

9. ASTM D5139-90, Standard Specification for Sample Preparation for Qualification Testing of Coatings to be Used in Nuclear Power Plants, American Society for Testing and Materials, West Conshohocken, PA (1990)

10. ASTM D4214, Standard Test Method for Evaluating the Degree of Chalking of Exterior Paint Films; ASTM D4541-89, Standard Method for Pull-Off Strength of Coating Using Portable Adhesion Testers; $\quad$ ASTM D3359-90, Standard Test Method for Measuring Adhesion by Tape Test; D3912-89, Standard Test Method for Chemical Resistance of Coatings Used in Light-Water Nuclear Power Plants, American Society for Testing and Materials, West Conshohocken, PA (1990).

11. ASTM 3911-89, Standard Test Method for Evaluating Coating Used in Light-Water Nuclear Power Plants at Simulated Design Basis Accident (DBA) Conditions, American Society for Testing and Materials, West Conshohocken, PA (1989).

12. R. F. Creed, J. C. Fordham, and J. Mancilla, "Results of Background Dose Reduction and ALARA Efforts to Date," WHC-SD-SNF-PRS-001, Westinghouse Hanford Company, Richland, Washington (1996).

13. K. M. Jones, "Close-out report for hydrolasing recirculation piping in $105 \mathrm{~K}$ East Basin," WHC-SD-ECOR-001, Westinghouse Hanford Company, Richland, Washington (1996). 14. F. H. Huang, "Refinishing contaminated floors in spent nuclear fuel storage basins," submitted for publication in Waste Management, HNF-SA-3187-FP, Fluor Daniel Northwest, Inc., Richland, Washington (1997).

15. R. F. Creed, "Functions and requirements for the $105 \mathrm{~K}$ East Basin dose reduction project," WHC-SD-SNF-FRD-001, Westinghouse Hanford Company, Richland, Washington (1994). 
Figure $1105 \mathrm{~K}$ Storage Basin for Spent Nuclear Fuel 
Figure 2 Clean and Coat Equipment 
Figure 3 Dose Rate Profile With Basin Water Level at $4.9 \mathrm{~m}$. Average Dose Rate: $10 \mathrm{mrem} / \mathrm{h}$ [12]. 
Figure 4 Dose Rate Profile With Basin Water Level at $4.98 \mathrm{~m}$. Average Dose Rate: $6 \mathrm{mrem} / \mathrm{h} \mathrm{[12]}$. 